\title{
"Methodological bases of estimating the efficiency of economic security management of the enterprises in the global environment"
}

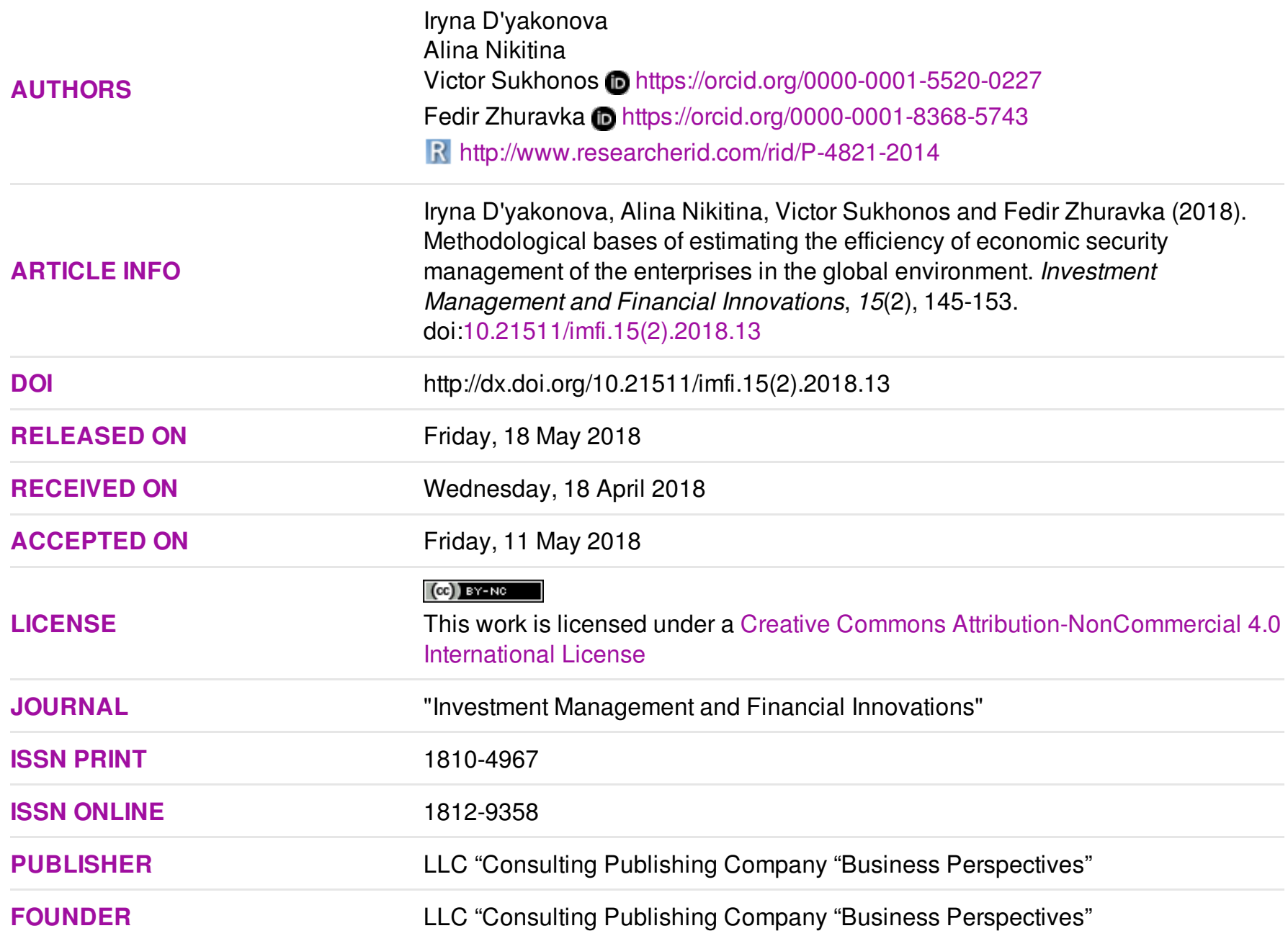

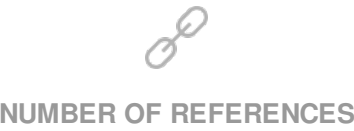

22
NUMBER OF FIGURES

2

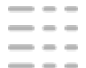

NUMBER OF TABLES

3

(C) The author(s) 2022. This publication is an open access article. 


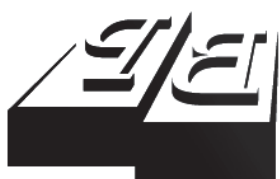

BUSINESS PERSPECTIVES

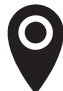

LLC "CPC "Business Perspectives" Hryhorii Skovoroda lane, 10, Sumy, 40022, Ukraine

www.businessperspectives.org

Received on: $18^{\text {th }}$ of April, 2018 Accepted on: $11^{\text {th }}$ of May, 2018

(C) Iryna D'yakonova,

Alina Nikitina, Victor Sukhonos,

Fedir Zhuravka, 2018

Iryna D'yakonova, Doctor of Economics, Professor, Department of International Economics, Sumy State University, Ukraine.

Alina Nikitina, Ph.D. in Economics, Associate Professor, Department of International Economics, Kharkiv National Automobile and Highway University, Ukraine.

Victor Sukhonos, Doctor of Law, Professor, Department of Criminal and Legal Disciplines and Judicial Proceedings, Sumy State University, Ukraine.

Fedir Zhuravka, Doctor of Economics, Professor, Department of International Economics, Sumy State University, Ukraine.

\section{(ㄷ)(1) (8)}

This is an Open Access article, distributed under the terms of the Creative Commons Attribution-NonCommercial 4.0 International license, which permits re-use, distribution, and reproduction, provided the materials aren't used for commercial purposes and the original work is properly cited.
Iryna D’yakonova (Ukraine), Alina Nikitina (Ukraine), Victor Sukhonos (Ukraine), Fedir Zhuravka (Ukraine)

METHODOLOGICAL BASES

OF ESTIMATING THE EFFICIENCY

OF ECONOMIC SECURITY

MANAGEMENT OF THE ENTERPRISES

IN THE GLOBAL ENVIRONMENT

\begin{abstract}
The article analyzes concepts to determining the essence of the economic security management at an enterprise. The main features of identifying the effectiveness of economic security management at the enterprise are stipulated. The theoretical and methodological approach to determining the effectiveness of economic security management of the enterprise is proposed, which allows to identify the threats and predict their consequences, to provide internal balance in the enterprise activity and the compliance of its mission and strategic direction of the activity with its key interests. Moreover, it is proposed to use the matrix of comparing the level of the enterprise economic security (EES) and the total impact on the EES level in one of the scenarios (pessimistic, optimistic, and most probable), which allows to assess the effectiveness of the economic security management of the enterprises and provide recommendations to increase the latter, minimizing destructive effects of dominant threats in the context of certain functional components of the economic security.
\end{abstract}

Keywords

JEL Classification management, economic security of the enterprise, interrelation, security, efficiency

\section{INTRODUCTION}

The Ukraine's integration into the world economic space on a parity basis puts a number of tasks for the domestic economy, first of all, in formulating principles and methods of combining national and international interests. The primary task of business entities of the Ukrainian economy is to work out adaptive mechanisms that can respond quickly to changes, which take place in the global environment and to adapt to them in a proper way. A perfect national internal institutional, financial and economic structure, including the microeconomic level, is the key to integrating into the world financial and economic space on a parity basis.

Nowadays, Ukraine moves towards creating effective market mechanisms of management. Under such conditions, the most acute issues for domestic enterprises are the competitiveness of goods, services and the image of enterprises in the market; adjusting plans at minimal resource losses; investment support of production; analysis of the influence of internal and external factors of management; determining deviations during the implementation of strategic and tactical plans, programs of an enterprise, etc. In this context, the requirements for the flexible management system of an enterprise increase, and the objective process is to improve its methods based on ensuring the eco- 
nomic security of enterprises as a whole. Not considering the peculiarities of the managerial process of economic security may result in low productivity, low production efficiency, loss of competitive advantages of the economic entity, etc. Thus, the objective and one of the extraordinary issues is developing the enterprise economic security management (EESM).

\section{LITERATURE REVIEW}

A large and growing body of literature has investigated the theoretical and methodical principles of management activity as a whole, and economic security management of enterprises in particular. An important point is disclosing the concept of "management", since the latter proves its multidimensionality and complexity both from the theoretical and applied standpoint. It should be emphasized that the concept under study is considered from a very diverse point of view, namely: in a static system (Shavaev, 1995; Kaplan \& Norton, 1992) - as a set of methods and approaches (Gitaazulin \& Kitsenko, 2014), management apparatus (Gerchikova, 2003; Sadekov \& Tsuric, 2006; Fathudinov, 2003), and in dynamic system - as a set of functions (Ansoff, 1989; Porshev et al., 2003), the process (Gitaazulin \& Kitsenko, 2014; Ansoff, 1989; Porshev et al., 2003), and targeted influence (Gitaazulin \& Kitsenko, 2014; Shynkarenko \& Bondarenko, 2003).

Note that in general, management is understood as a continuous effect on a managed object, aimed at achieving the goals set. In addition, the level of achievement determines the management effectiveness in general and the effectiveness of its instruments in particular (Ansoff, 1989; Vasylenko \& Tkachenko, 2003).

By the end of the 90s of the last century, the attention of scholars was directed to developing and studying of the concepts of national economic security.

Security studies specialists working within traditional neorealist frameworks tend to such sources as poverty, environmental hazards, and economic recessions, or to focus on the security concerns of individuals rather than those of states (Walt, 1991). Security studies scholars subscribe to a narrow concept of economic security, that is located within a traditional national security framework of analysis (Kolodziej, 1992, p. 422). Geo-economics also replaced geo-politics as the central pre-occupation of the major powers in the 1990s, with economic power recognized as crucial in determining the primacy or subordination of states in the international system (Luttwak, 1990; Huntington, 1993, p. 72; Moran, 1993).

Many recent studies of the national researchers Nikolayuk and Nikiforchuk (2005, p. 205), Yurovich (1995), Kovalev and Sukhorukov (1998), Kozachenko, Ponomarev, and Lyashenko (2003), Oleynikova and Illiashenko (2016), Oleynikov (1997) have shown that the scholars focused on the problem of determining the essence of economic security by revealing the essence of economic security, factors that influence it, as well as approaches to determining the essence of such concept as "enterprise economic security".

For example, Nikolayuk and Nikiforchuk (2005, p. 205) define the economic security of an enterprise as a complex category that characterizes the ability of the systems created at the enterprise to withstand the destabilizing effects of internal and external factors in order to ensure the efficient use of its resources (capital, personnel, technology, information, technology, etc.), existing market opportunities (competitiveness), as well as fulfillment of other. Yurovich (1995) defines the company's economic security as the protection of the enterprise against negative impacts of external and internal environment, the ability to eliminate various threats quickly or adapt to external conditions without negative consequences for the enterprise. Business conditions under which the entity, using the corporate resources in the most efficient way, prevents or eliminates the influence of existing threats or other unforeseen circumstances or protects itself against them, and, in general, ensures achieving the main business objectives in the conditions of competition and economic risk (Kovalev \& Sukhorukov, 1998, p. 48). Protectability of a busit ness entity from the negative effects of external environment, as well as the ability to eliminate 
quickly various threats or adapt to existing conditions that do not affect its activities negatively (Kozachenko, Ponomarev, \& Lyashenko, 2003, p. 87). The process aimed at protecting the entrepreneurial structures and individuals whose activities include elements of entrepreneurship against criminal competitiveness and other methods that harm them due to violation of law and business ethics (Oleynikov, 1997, p. 138). One important topic emerges from the studies discussed so far: "enterprise economic security" can be attributed to several approaches, which characterizes the phenomenon of economic security as a complex interdisciplinary category and represents its adequate qualities.

Together, these studies provide important insights into the economic security management of enterprises and the estimation of its efficiency.

Despite the multiplicity of researches on this issue, scientific approaches still differ in aspects concerning the estimation of economic security management of enterprises. For today, the tools and instruments of the estimation of economic security management of enterprises are not sufficiently studied. As shown above, the authors of scientific publications consider only certain aspects of the economic security management of enterprises and the estimation of its efficiency.

\section{AIM AND METHODS}

The main purpose of the article is to develop the theoretical foundations of the enterprise economic security, to work out and substantiate the process of managing the enterprises economic security in the global environment. The conceptual goal of the paper is to develop a theoretical and methodological approach to determining the effectiveness of the enterprise economic security management, which will provide an opportunity for clear identification of threats and prediction of their consequences, will ensure the correspondence of its mission and strategic direction to the system of priority interests under the globalization. The information base of the study consisted of statistical materials of Ukraine and those of countries of the world, special economic literature, materials of research and practice conferences, periodicals of leading foreign and Ukrainian scientists, as well as the results of authors' own observations.

In order to achieve this goal, the following general scientific and special methods and techniques were used: abstract-logical method, analysis and synthesis - to shape and substantiate the system of economic security management of the enterprise; generalization and abstraction - to study the categorical basis of economic security, theoretical foundations and tools for managing the economic security of enterprises; matrix method - to develop a matrix for comparing the degree of exposure to threats and the effective management of the enterprise economic security.

\section{RESULTS}

The turbulence in the development of the world economy creates new challenges for the economy of Ukraine as a whole, as well as for business entities of all economic sectors in particular. Among the main factors causing the economic development instability and increasing the pressure on the financial and economic security of Ukrainian enterprises, one should distinguish: the decrease of world prices for the products of the mining and metallurgical complex, the growth of interest rates in the world, which directly affects the increasing the cost of servicing the external debt of Ukraine and accelerating the global GDP growth. The IMF forecasts acceleration of global GDP growth from $3.1 \%$ in 2016 to $3.5 \%$ in 2017 and $3.6 \%$ in 2018. Against the background of obtaining a EU visa-free regime for Ukraine, which, first of all, should contribute to extension of political, economic and cultural relations with the EU and has a long-term impact on the development of the economy and financial stability of Ukraine, it is necessary to correctly evaluate the growing risk of labor migration of the able-bodied population to EU countries.

The analysis of globalization and internationalization processes in the world economy points to a deep and increasingly intense interconnection between countries. Thus, according to the World Trade Organization, since the beginning of 2017, the volume of international trade in goods and services amounted to over USD 6.5 trillion, which 
exceeds a similar figure by more than $8 \%$ in the previous year (World Trade Organization, n.d.). As in the past year, the leader in the growth of export of goods is China; in absolute value, its exports amounted to USD 1.05 trillion. As for indicators of the EU market international trade, it is worth emphasizing moderate growth rates of 5\%. In total, the balance of foreign trade in the EU changed its value from a surplus of USD 7 billion in January-June 2016 for a deficit of USD 3 billion. In addition, according to the UN Conference on Trade and Development (UNCTAD), global foreign direct investment, the main recipients of which will be the United States, China and India, will grow by $5 \%$ or almost USD 1.8 trillion in absolute terms in 2017. The main reasons for this increase are the expected high growth rates in the largest regions, the recovery of world trade and corporate profits (UNCTAD, n.d.).

The conducted research allows to assert that the management of the enterprise economic security holds a special place in the management system of the organization, since, in a market economy, it strengthens the adaptability, business competitiveness, ensuring the economic processes integration at the enterprise and connecting internal resources and the external environment.

Based on weighted analysis of the management tools, the conclusion is made that the enterprise economic security management in the context of information signals about the danger of reducing the enterprise performance, imperfect methods of planning, adjustment, organization of production, mismatch of the existing objectives of the enterprise and the requirements of the environment should include such an efficient subsystem information-analytical service that would be aimed at improving the quality and effectiveness of management due to prioritization. Therefore, it was considered expedient to introduce a system of economic security management at the enterprise, which involves all management functions integration, provides a methodological and instrumental basis for the economic security management (Figure 1).

In addition, combining purposeful subsystems of the analysis of the state and dynamics of enterprise development, and with a view to anticipate the threat and take necessary measures for its protection and counteraction, as well as successful functioning in the future, economic security management of the enterprise provides diagnostics of the state of the enterprise that allows to study properly the complex factors threatening the enterprises activity.

Note that it is necessary to coordinate the system of measures to ensure the EES with its objectives and resources taking place at a specific enterprise. Equally targeted are the vectors of the main objectives and a set of measures to ensure the enterprise economic security level.

According to the systems theory, one of the most important internal characteristics of any dynamic system is its state $z(t)$, where value at a given time $t$ determines the outcome value or the output of the system $y(t)$. Moreover, the state of the system $z(t)$ at a certain time $t$ can be expressed as a vector:

$z(t)=z_{i}(t)_{i=1}^{n}=\left(z_{1}(t), z_{2}(t), \ldots, z_{n}(t)\right)$,

where $z_{i}(t)$ - basic coordinates of the system.

Being permanently influenced by various external and internal factors and aiming to achieve the purpose, the system movement or its maintenance in a certain set of desirable states becomes possible during a focused and rational set of measures on organization and coordination using available opportunities and resources, that is, management, the effectiveness of which is determined by the degree of the goals achievement.

Consider the enterprises economic security (EES) as the state of the entity, which is the result of a targeted measures to avoid, weaken, localize or adapt the threats impact at the minimum losses and time intervals that are acceptable and economically justified for the enterprise managers. Moreover, it was proposed to consider the effective management of the enterprise economic security (EESM) as the desired state deviation (the level of economic security of the indicative enterprise) and the current state deviation (level of EES):

$$
E_{E E S M_{i}}=\frac{z_{\text {desired }}^{\Pi_{e}}(t)-z_{\text {current }}^{\Pi_{i}}(t)}{z_{\text {desired }}^{\Pi_{i}}(t)},
$$


Source: Elaborated by the authors.

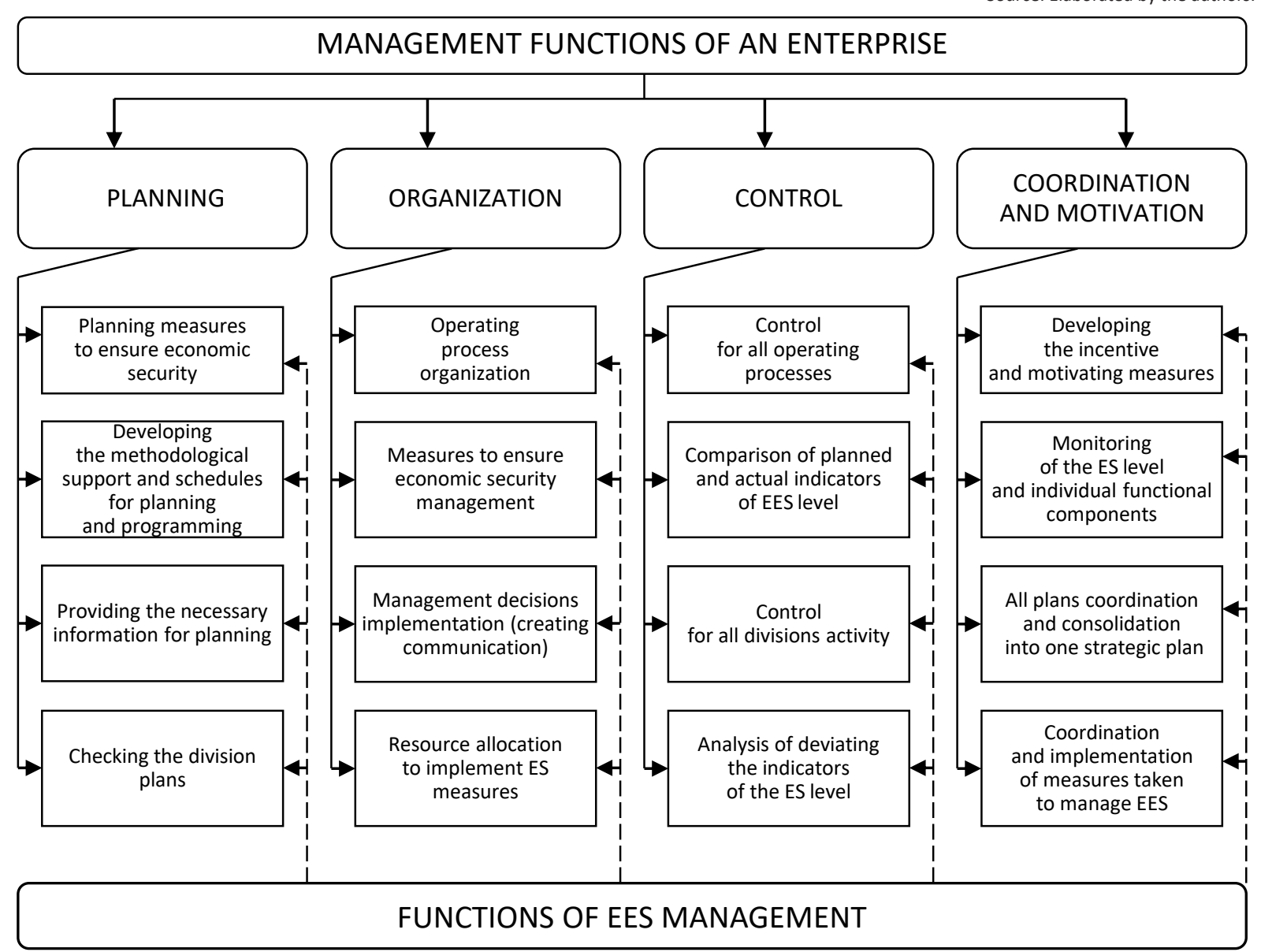

Figure 1. Relationship between the functions of economic security management and enterprise management

where $E_{E E S M}$ - indicator of the effectiveness of the EES management, $z_{\text {desired }}^{\Pi_{e}}(t)$ - the desired state of the indicative enterprise's $E S, z_{\text {current }}^{\Pi_{i}}(t)$ - the current state of $E S$ of $i$-th enterprise.

It is worth to agree with Kamyshnikova (2010) who emphasizes that there is not yet a unified scale for assessing the EES level, since a wide range of methodological tools for assessing the EES level results from the influence of numerous factors on it, namely: the choice of the number of the ES level intervals, the tasks and objectives of the analysis, the calculations actuality, industry characteristics, etc. Given the specified thesis, we propose to divide the obtained results of the EESM efficiency indicator, which demonstrates the changes that took place while taking economic security management measures (in percentage) into three zones, demonstrating the determined indicator deviation from the average of the proposed sample, thus distributing the limits of the latter (Table 1).
Thus, a negative value (below 0 ) received during the calculation indicates ineffective management influence on economic security and the need for adequate managerial intervention in the enterprise activity, which covers a number of reasonable management measures aimed at adjusting the parameters of individual functional components, levelling the influence of the dominant threats in order to increase the level of economic security of the business entity.

The close to zero value of the EESM efficiency indicator may denote no changes in the state of the control object and indicates the need to identify the factors that have caused this situation. The additional value of the EESM performance indicator points to a positive change in the level of economic security that determines the effective management of the economic security of the business entity. 
Table 1. Scale for assessing the EESM effectiveness

Source: Nikitina (2013).

\begin{tabular}{|c|c|c|}
\hline \multicolumn{2}{|c|}{$\begin{array}{l}\text { Value of the EESM } \\
\text { efficiency indicator } \\
E_{E E S M_{i}} / \text { level }\end{array}$} & Characteristics \\
\hline Case I & $\begin{array}{l}\text { Negative value/ } \\
\text { low level }\end{array}$ & $\begin{array}{l}\text { The low or critical level of EESM; inadequate attention is given to the EES provision. There is } \\
\text { an urgent need to take measures to minimize the impact of threats and increase the economic } \\
\text { security level. The value of the indicators of all functional components of economic security } \\
\text { belongs to the group of critical, unacceptably low, characterizing the low level of solvency, } \\
\text { creditworthiness, financial dependence of the enterprise on external (credit) resources, low level } \\
\text { of employees encouragement, lack of measures to ensure the proper level of technological process } \\
\text { (share of fixed assets with a high coefficient of physical wear (more than } 60 \% \text { ), poor support for } \\
\text { information and legal departments, non-compliance (or partial compliance) with legislation on } \\
\text { environmental issues, etc. }\end{array}$ \\
\hline Case II & $\begin{array}{l}\text { Threshold value/ } \\
\text { moderate level }\end{array}$ & $\begin{array}{l}\text { Moderate level of EESM; inadequate attention is given to the EES provision issues. There is a need } \\
\text { to take measures to minimize the threats impact and increase the economic security level. The } \\
\text { values of the indicators of ES functional components are in the group of permissible, average } \\
\text { permissible in the industry, although in some of the functional components (information, political } \\
\text { and legal, environmental), somewhat low values of the EES indicators are observed. }\end{array}$ \\
\hline Case III & $\begin{array}{l}\text { Additional value/ } \\
\text { high level }\end{array}$ & $\begin{array}{l}\text { High level of EESM; significant attention is paid to the EES provision issues. There is a need to } \\
\text { monitor a set of measures to minimize the impact of threats and increase the level of economic } \\
\text { security. The values of the indicators of all (or almost all) functional components of economic } \\
\text { security are grouped higher than the average, or even higher than the normative values (in } \\
\text { particular, for the indicators of the financial component), which indicates a rather high level } \\
\text { of solvency, creditworthiness, financial independence of the enterprise from external (credit) } \\
\text { resources, high level of the employee encouraging, applying measures at the enterprise to ensure } \\
\text { an adequate level of technological process (proportion of fixed assets with a low index of physical } \\
\text { wear, no more than 30\%), high level of support for information and legal departments, observance } \\
\text { (or partial compliance) of legislation on environmental issues. }\end{array}$ \\
\hline
\end{tabular}

With a view to revealing the substantive essence of the EESM in terms of functional and technological aspects, a theoretical and methodical approach to determining the EESM efficiency is proposed, which involves the use of methodological tools for assessing the level of economic security (integral index of the EES level) and the total level of threat impact on the ES level (Figure 2).

It's necessary to consider the main stages of the proposed methodological approach. Thus, at the first stage, it is necessary to identify the objects (enterprises) to determine and justify a set of characteristics (indicators) and to form a matrix of input data for the evaluation. The second step is to assess the EES level by applying multidimensional factor analysis methods based on obtaining an integral indicator of the individual enterprise economic security, which is obtained by weighted convolution of individual estimates of values in hypothetical groups of factors, where the weights are the contributions of each of them to the explanation of the full dispersion of outcomes (Nikitina, 2015). The methodological approach to assessing the EES level was considered, distinguishing the EES's main functional components and ensuring the objective factor load of the groups of indicators that reflect the specifics of each business activity and can be adjusted with the change of time to be sound and appropriate, although rather laborious during calculations. At the next stage, the probability of the dominant threats to the EES is calculated using expert methods. To identify the potential total impact of threats on the EES level (TES), we propose to use the scale as presented in Table 2.

Table 2. Scale of estimating the total impact of threats on the enterprise economic security

Source: Elaborated by the authors.

\begin{tabular}{|c|c|c|}
\hline $\begin{array}{l}\text { Numerical range of the } \\
\text { indicator in a certain } \\
\text { scenario (total impact) }\end{array}$ & $\begin{array}{c}\text { Value } \\
\text { (degree } \\
\text { of impact) }\end{array}$ & Characteristics \\
\hline $0<W_{T E S_{i}} \leq 0.5$ & Low & $\begin{array}{l}\text { The probability of a threat is unlikely. The impact of threats on the economic } \\
\text { security level is insignificant, almost all indicators included in the methodological } \\
\text { tools for assessing the ES level, have not changed the value ( } 10 \% \text { at most). }\end{array}$ \\
\hline $0.5<W_{T E S_{i}} \leq 0.7$ & Moderate & $\begin{array}{l}\text { The threats occurrence is quite probable. The impact of threats on the ES level is } \\
\text { significant but not catastrophic, because the indicators' values change in descending } \\
\text { order (especially this is the case of financial component of the economic security). }\end{array}$ \\
\hline $0.7<W_{T E S_{i}} \leq 1.0$ & High & $\begin{array}{l}\text { The threats occurrence is likely. The impact of threats on the ES level is quite } \\
\text { significant, almost all indicators are aimed at low effect, there is a clear tendency } \\
\text { of critical values in terms of individual indicators of financial and innovation- } \\
\text { investment components. }\end{array}$ \\
\hline
\end{tabular}




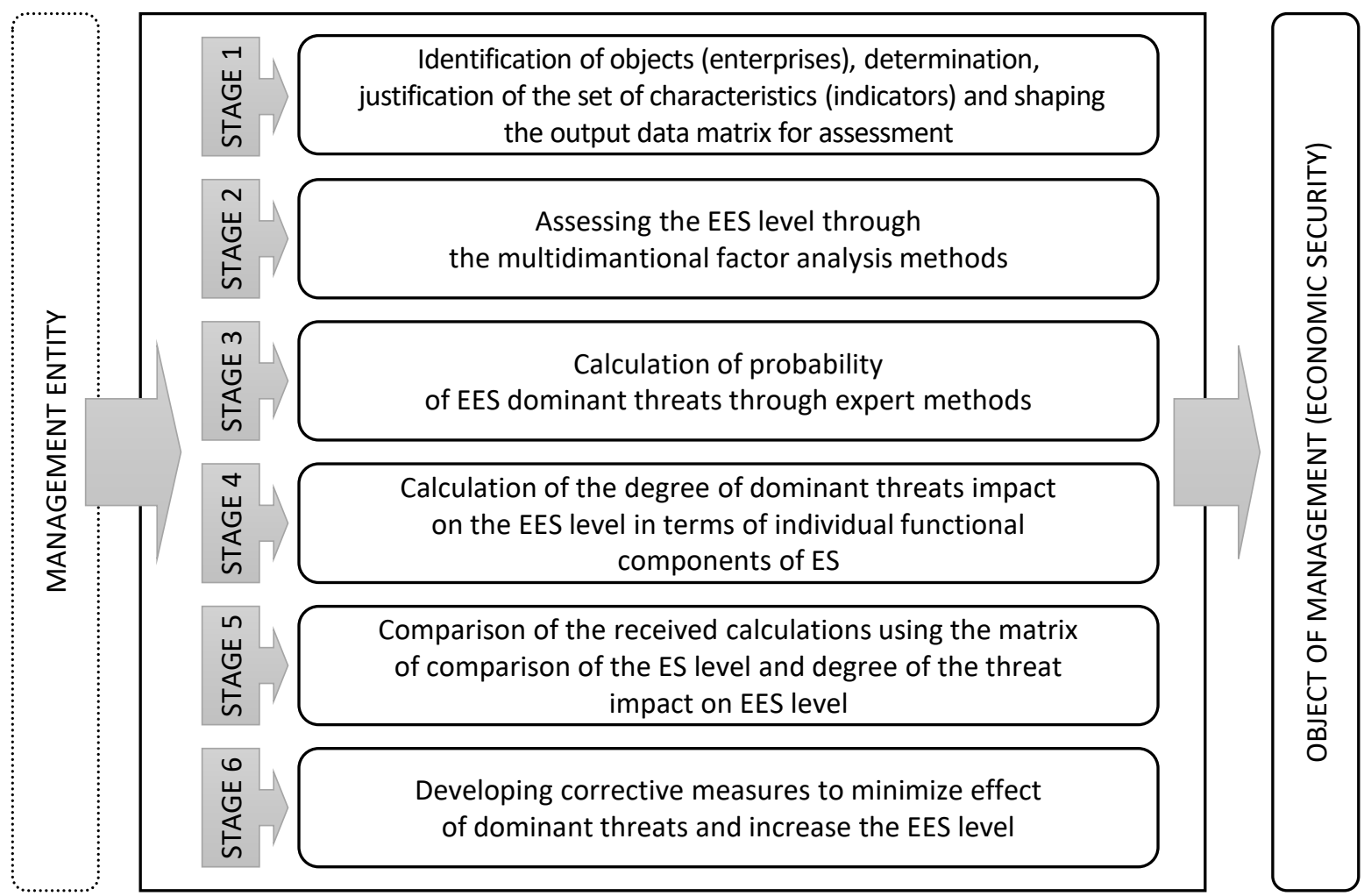

Figure 2. The scheme of implementing the theoretical and methodological approach to determining the EESM effectiveness

The next step is to calculate the degree of the dominant threats influence on the enterprise's ES level in the context of individual functional components of the EES.

According to the methodological approach proposed, it was suggested to interpret the received calculations of a separate enterprise using a matrix of comparing the ES level and the degree of the threat impact on the EES level, which is an important element of further studying the ES level, which reflects horizontally the importance of the EESM effectiveness indicator, and vertically - the total degree of the threat impact on the EES level in a given year (Nikitina, 2015) (Table 3).

Table 3. Matrix for comparing the indicator value of the EESM efficiency and the total degree of threats impact on the economic security

Source: Elaborated by the authors.

\begin{tabular}{l|c|c|c}
\hline $\begin{array}{c}\text { The indicator value of the EESM } \\
\text { efficiency }\end{array}$ & \multicolumn{2}{c}{$\begin{array}{c}\text { Total degree of impact of the threat on the EES level } \\
\text { (according to one of the forecast scenarios) }\end{array}$} \\
\cline { 2 - 3 } & Low level & Moderate level & High level \\
\hline High level & I & I & II \\
\hline Moderate level & II & III & III \\
\hline Low level & & III \\
\hline
\end{tabular}

Based on the comparison matrix results, each investigated enterprise holds an appropriate place in the matrix field, which contains nine elements according to the previous breakdown, distributing the results of the studied concepts in three zones: zone I - green zone; zone II - yellow zone; and zone III - red zone. Getting to a certain zone, a separate company receives specific recommendations for making management decisions on work and analysis of the EES level.

Consequently, zone I - green zone - all enterprises, which have fallen to the top left corner of the matrix, are characterized by the "sufficient man- 
ageability" of economic security, while the economic security management of such enterprises is, in general, quite effective, although sometimes it may be necessary to develop corrective recommendations or preventive measures.

Zone II - yellow zone - includes enterprises that are reflected in the elements of the main diagonal of the matrix, and the level of economic security can be characterized as "moderate manageability", although there is a need to develop rather strict measures in the economic security management, the necessary step is to calculate critical values of the obtained indicators and the minimum permissible level of relative deviation in the calculation period.

The last is the third, red zone - the right bottom corner of the matrix - the zone of further careful study and analysis of those enterprises that fall into it, and economic security can be interpreted as "low management", which may result in the impossibility of strengthening its level, or there will be an urgent, immediate need for a significant correction of EESM, which will require extensive analytical work based on constantly received and processed information using expensive technical systems and technologies that provide market data entry and processing in real time.

The timely detection of negative trends in development and the threats impact on the EES level is a prerequisite for effective management of the business entities economic security, therefore, the use of the matrix for comparing the level of economic security and the total impact on the EES level according to one of the scenarios (pessimistic, optimistic, most probable) will allow to assess the economic security management effectiveness at the enterprise and provide recommendations for raising the level of the latter, minimizing the destructive influence of the dominant threats in the context of certain functional components of the economic security.

\section{CONCLUSION}

It has been determined that the management of the enterprise economic security holds a special place in the management system of the enterprise, since, in a market economy, it strengthens the adaptability and business competitiveness, ensuring the economic processes integration of the enterprise and connecting internal resources and the external environment. In order to increase the enterprise management efficiency, a theoretical and methodological approach to determining the effectiveness of economic security management at the enterprise is proposed, which will provide an opportunity for clear identification of threats and their consequences forecasting, will provide internal balance in the activities of the enterprise and the compliance of its mission and strategic direction to its priority interests. Moreover, it is proposed to use the matrix of comparing the effectiveness of economic security management and the total impact on the economic security level in one of the scenarios (pessimistic, optimistic, and most probable), which will allow to assess the effectiveness of the economic security management at the enterprises and provide recommendations for raising the level of the latter, minimizing destructive effects of dominant threats in the context of certain functional components of the economic security.

\section{REFERENCES}

1. Ansoff, I. (1989). Стратегическое управление [Strategicheskoe upravlenie] (519 p.). Moskow: Economics.

2. D’yakonova, I., Mordan, Y., \& Sokolenko, K. (2015). The methodical framework of the development of adequate model of estimation of credit risk of the bank. Corporate Ownership and Control, 13(1), 769-773.
3. Fathudinov, V. G. (2003). Производственный менеджмент [Proizvodstvennyy menedzhment] (491 p.). SPb.: Peter.

4. Gerchikova, I. N. (2003). Менеджмент [Menedzhment] (501 p.). Moskow: UNITY.

5. Gitaazulin, T. M., \& Kitsenko, Т. М. (2014). Виявлення зони атракції в економічній системі на основі оцінювання форм розподілу показників структурних елементів [Vyiavlennia zony atraktsii v ekonomichnii systemi na osnovi otsiniuvannia form rozpodilu pokaznykiv strukturnykh elementiv]. Effective Economics, 4, 87-95.

6. Kamyshnikova, E. V. (2010). Формирование универсальной шкалы оценки уровня 
экономической безопасности предприятия [Formirovaniye universalnoy shkaly otsenki urovnia ekonomicheskoy bezopasnosti predpriyatiya]. Economy: Problems of Theory and Practice, 41. Retrieved from http://www.stattionline.org.ua/ ekonom/60/8041-formirovanieuniversalnoj-shkaly-ocenkiurovnya-ekonomicheskoj-bezopasnosti-predpriyatiya.html

7. Kaplan, R. S., \& Norton, D. P. (1992). The Balanced Scorecard Measures that Drive Performance (314 p). Harvard Business Review.

8. Kovalev, D., Sukhorukova, Т. (1998). Экономическая безопасность предприятия [Ekonomicheskaya bezopasnost predpriyatiya]. Economy of Ukraine, 10, 48-51.

9. Kozachenko, A., Ponomarev, V., Liashenko, А. (2003). Экономическая безопасность предприятия: сущность и механизм обеспечения [Ekonomicheskaya bezopasnost predpriyatiya: suschnost i mekhanizm obespecheniya]. Kyiv: Libra.

10. Nikitina, A. V. (2013). Методичний інструментарій оцінювання рівня економічної безпеки підприємств на підгрунті використання методів факторного аналізу [Metodychnyi instrumentarii otsiniuvannia rivnia ekonomichnoi bezpeky pidpryiemstv na pidhrunti vykorystannia metodiv faktornoho analizu]. Business-Inform, 8, 139-144.

11. Nikitina, A. V. (2015). Управління економічною безпекою підприємства в умовах глобалізаційних перетворень [Upravlinnia ekonomichnoiu bezpekoiu pidpryiemstva v umovakh hlobalizatsiinykh peretvoren]. Odesa National University of Economics, 3(58), 144-150.

12. Nikolaiuk, S., Nykyforchuk, D. (2005). Безпека суб'єктів підприємницької діяльності: курс лекцій [Bezpeka subiektiv pidpryiemnytskoi diialnosti: kurs lektsii] (320 p.). Kyiv: KNT.

13. Oleynikova, Е. (1997). Основы экономической безопасности (государство, регион, предприятие, личность) [Osnovy ekonomicheskoy bezopasnosti (gosudarstvo, region, predpriyatie, lichnost) (288 p.). Moscow: ZAO "Byznesshkola "YntelSyntez".

14. Porshnev, A. G., Rumyantsev, Z. P., \& Salomatin, N. A. (2003). Управление организацией [Upravlenie organizatsiey] (716 p.). Moskow: INFRA-M.

15. Sadekov, A. A., \& Tsurik, V. V. (2006). Управление предприятием в условиях кризиса [Upravlenie predpriyatiem $v$ usloviyakh krizisa] (178 p.). Donetsk: Don. State University of Economics.
16. Shavaev, A. G. (1995).

Криминологическая безопасность негосударственных объектов экономики [Kriminologicheskaya bezopasnost negosudarstvennykh obektov ekonomiki] (126 p.). Moskow: INFRA-M.

17. Shynkarenko, V., \& Bondarenko, А. (2003). Управление конкурентоспособностью предприятия [Upravlenie konkurentosposobnostyu predpriyatiya] (186 p.). Kharkiv: HNADU.

18. UNCTAD (n.d.). Retrieved from http://unctad.org/

19. Vasylenko, V. A., \& Tkachenko, T. I. (2003). Стратегічне управління [Stratehichne upravlinnia] (396 p.). Kyiv: ZUL.

20. Yurovych, L. (2009). Економічна безпека підприємства: сутність, чинники впливу, основні проблеми [Ekonomichna bezpeka pidpryiemstva: sutnist, chynnyky vplyvu, osnovni problemy]. Retrieved from http:// ena.lp.edu.ua:8080/bitstream/ ntb/4894/1/95.pdf

21. Walt, Stephen M. (1991). The Renaissance of Security Studies. International Studies Quarterly, 35(2), 211-239.

22. World Trade Organization (n.d.). Retrieved from http://www. un.org/ 